\title{
Digestible tryptophan:digestible lysine ratio in diets for laying hens from 24 to 40 weeks of age
}

\author{
Arele Arlindo Calderano', Paulo Cezar Gomes², Juarez Lopes Donzele², Sergio Luiz de Toledo \\ Barreto ${ }^{2}$, Cássia Rampini Vellasco ${ }^{1}$, Heloisa Helena de Carvalho Mello ${ }^{1}$, Guilherme Rodrigues \\ Lelis ${ }^{1}$, Tatiana Cristina da Rocha ${ }^{1}$
}

\footnotetext{
${ }^{1}$ Pós-graduação em Zootecnia, UFV - Viçosa, MG.

${ }^{2}$ Departamento de Zootecnia, UFV - Viçosa, MG.
}

\begin{abstract}
The objective of this study was to determine the ideal digestible tryptophan:digestible lysine ratio in diets for laying hens from 24 to 40 weeks of age. Two hundred and forty Hy-Line W-36 laying hens at 24 weeks of age were distributed in a completely randomized design, with five treatments, eight replicates and six birds per experimental unit. The digestible tryptophan levels in the experimental diets were $1.57 ; 1.68 ; 1.79 ; 1.90$ and $2.01 \mathrm{~g} / \mathrm{kg}$, providing ratios of digestible tryptophan:digestible lysine of $0.215 ; 0.230 ; 0.245 ; 0.260$ and 0.275 . The increase in the levels of digestible tryptophan in the diet linearly improved the feed intake, digestible tryptophan intake, digestible lysine intake, egg production, egg mass, feed conversion per egg mass and utilization efficiency of digestible lysine for eggs mass. There were quadratic effects from the digestible tryptophan levels on egg weight. For the efficiency of utilization of digestible lysine for egg mass, there was better adjustment of the data to the LRP model. The level of digestible tryptophan in the diet from which the plateau occurred was $0.184 \%$. This level corresponded to the intake of $142 \mathrm{mg} / \mathrm{bird} /$ day of digestible tryptophan and digestible tryptophan:digestible lysine ratio of 0.252 . The ideal digestible tryptophan:digestible lysine ratio recommended in diets for laying hens from 24 to 40 weeks of age is $0.252(25.2 \%)$.
\end{abstract}

Key Words: amino acid, birds, ideal protein

\section{Introduction}

Modern laying hens are able to achieve high indexes of productivity. However, for this, it is essential that they receive diets with adequate levels of amino acids. Besides the components of body and egg proteins, the amino acids are precursors of specialized products important in the metabolism.

A milestone in the nutrition of monogastrics was the application of the concept of ideal protein in diet formulations. This allowed a better balance of amino acids in the diets and a better fulfillment of requirements of the birds. Thus, studies with amino acids should be focused on the establishment of ideal ratios between the essential amino acid and lysine, in which it is important to evaluate to which extent the industrial amino acids can be added to the diets, considering productive, environmental and economic aspects.

The absolute requirements of amino acids of the birds are largely influenced by genetic factors, the rate of production and environmental factors. However, the ratios between them are much less influenced (Bregendahl et al., 2008), so it is more important to determine the ideal ratios between amino acids rather than the absolute requirement of the birds for each amino acid. Furthermore, the ideal profile of amino acids for commercial laying hens is not well established in the literature.

Tryptophan is considered the third limiting amino acid in diets based on corn and soybean meal for laying hens (Russell \& Harms, 1999; Harms \& Russell, 2000; Peganova et al., 2003; Deponti et al., 2007). However, few studies have been conducted to determine the requirement of digestible tryptophan and especially its ideal ratio with digestible lysine in diets for laying hens.

The objective of this study was to determine the ideal digestible tryptophan:digestible lysine ratio in diets for laying hens from 24 to 40 weeks of age.

\section{Material and Methods}

The experiment was conducted at the Poultry Section of the Departamento de Zootecnia, in Universidade Federal de Viçosa. Two hundred and forty Hy-Line W-36 laying hens at 24 weeks of age, with initial average weight of $1,267 \mathrm{~g}$ were used.

Birds were housed in pairs in $25 \times 40 \times 45 \mathrm{~cm}$ cages, installed in a poultry house of dimensions $12 \times 8 \mathrm{~m}$, closed 
in the sides with wire mesh and covered with gable roofs of clay tiles. When birds completed 22 weeks of age, they were weighed and distributed in a completely randomized design with five treatments and six replicates, at eight birds per experimental unit. Egg production was recorded during the period of 22-24 weeks of age. Before providing the experimental diets, birds were standardized in the treatments according to egg production.

When completing 24 weeks of age, birds were subjected to experimental treatments that consisted of diets with the same amount of nutrients, except for the levels of digestible tryptophan. A suboptimal level of digestible lysine in the $\operatorname{diet}(7.30 \mathrm{~g} / \mathrm{kg})$ was used for an expected daily intake/bird of $95 \mathrm{~g}$ of feed and $694 \mathrm{mg}$ of digestible lysine.

The suboptimal level was important to ensure that all digestible lysine consumed was used and that the digestible tryptophan:digestible lysine ratio estimated reflected the real needs of birds. The digestible tryptophan levels in the experimental diets were $1.57 ; 1.68 ; 1.79 ; 1.90 ;$ and $2.01 \mathrm{~g} / \mathrm{kg}$, providing digestible tryptophan:digestible lysine ratios of $0.215 ; 0.230 ; 0.245 ; 0.260$; and 0.275 (Table 1 ).

The supplementation with L-tryptophan was done to replace the L-glutamic acid in protein equivalent. After this substitution, the inert (starch) was added at the amount needed to balance the diets. The same ratios between lysine and other amino acids were maintained in all the diets.

The minimum ratio between the essential amino acids and lysine met in the diets were: methionine + cystine, 1.030 (1.00 recommended by Brumano (2008) + addition of 0.030$)$; threonine, 0.810 ( 0.780 recommended by Rocha et al. (2009) + addition of 0.030); and methionine, 0.530, valine, 0.930 and isoleucine, 0.860 (values recommended by Rostagno et al. (2005) + addition of 0.030).

The increase of 0.030 in the ratios was aimed at preventing the lack of some essential amino acid, because if any of the ratios were underestimated, the performance

Table 1 - Composition and nutritional value of the diets in natural matter

\begin{tabular}{|c|c|c|c|c|c|}
\hline Composition (g/kg) & Treatment 1 & Treatment 2 & Treatment 3 & Treatment 4 & Treatment 5 \\
\hline Corn $(80 \mathrm{~g} / \mathrm{kg})$ & 649.41 & 649.41 & 649.41 & 649.41 & 649.41 \\
\hline Soybean meal (450 g/kg) & 150.46 & 150.46 & 150.46 & 150.46 & 150.46 \\
\hline Corn gluten meal (600 g/kg) & 30.00 & 30.00 & 30.00 & 30.00 & 30.00 \\
\hline Soybean oil & 35.64 & 35.64 & 35.64 & 35.64 & 35.64 \\
\hline Limestone & 97.94 & 97.94 & 97.94 & 97.94 & 97.94 \\
\hline Dicalcium phosphate & 16.84 & 16.84 & 16.84 & 16.84 & 16.84 \\
\hline Salt & 5.560 & 5.560 & 5.560 & 5.560 & 5.560 \\
\hline Potassium carbonate & 2.720 & 2.720 & 2.720 & 2.720 & 2.720 \\
\hline Choline chloride $(600 \mathrm{~g} / \mathrm{kg})$ & 0.400 & 0.400 & 0.400 & 0.400 & 0.400 \\
\hline Antioxidant ${ }^{1}$ & 0.100 & 0.100 & 0.100 & 0.100 & 0.100 \\
\hline Vitamin mixture $^{2}$ & 1.000 & 1.000 & 1.000 & 1.000 & 1.000 \\
\hline Mineral mixture ${ }^{3}$ & 0.500 & 0.500 & 0.500 & 0.500 & 0.500 \\
\hline L-lysine HCl (790 g/kg) & 2.320 & 2.320 & 2.320 & 2.320 & 2.320 \\
\hline DL-methionine $(990$ g/kg) & 3.080 & 3.080 & 3.080 & 3.080 & 3.080 \\
\hline L-threonine $(980 \mathrm{~g} / \mathrm{kg})$ & 1.260 & 1.260 & 1.260 & 1.260 & 1.260 \\
\hline L-isoleucine (985 g/kg) & 1.000 & 1.000 & 1.000 & 1.000 & 1.000 \\
\hline L-valine $(985 \mathrm{~g} / \mathrm{kg})$ & 0.820 & 0.820 & 0.820 & 0.820 & 0.820 \\
\hline L-tryptophan $(980$ g/kg) & 0.260 & 0.370 & 0.490 & 0.600 & 0.710 \\
\hline L-glutamic acid & 0.690 & 0.530 & 0.340 & 0.180 & - \\
\hline Starch & - & 0.050 & 0.120 & 0.170 & 0.240 \\
\hline \multicolumn{6}{|l|}{ Nutritional composition (g/kg) } \\
\hline Crude protein & 145.0 & 145.0 & 145.0 & 145.0 & 145.0 \\
\hline Metabolizable energy (kcal/kg) & 3,000 & 3,000 & 3,000 & 3,000 & 3,000 \\
\hline Calcium & 42.30 & 42.30 & 42.30 & 42.30 & 42.30 \\
\hline Available phosphorus & 3.950 & 3.950 & 3.950 & 3.950 & 3.950 \\
\hline Potassium & 6.150 & 6.150 & 6.150 & 6.150 & 6.150 \\
\hline Chloride & 3.720 & 3.720 & 3.720 & 3.720 & 3.720 \\
\hline Sodium & 2.370 & 2.370 & 2.370 & 2.370 & 2.370 \\
\hline Digestible tryptophan & 1.570 & 1.680 & 1.790 & 1.900 & 2.010 \\
\hline Digestible lysine & 7.300 & 7.300 & 7.300 & 7.300 & 7.300 \\
\hline Digestible methionine + cystine & 7.520 & 7.520 & 7.520 & 7.520 & 7.520 \\
\hline Digestible methionine & 5.340 & 5.340 & 5.340 & 5.340 & 5.340 \\
\hline Digestible threonine & 5.910 & 5.910 & 5.910 & 5.910 & 5.910 \\
\hline Digestible isoleucine & 6.280 & 6.280 & 6.280 & 6.280 & 6.280 \\
\hline Digestible valine & 6.790 & 6.790 & 6.790 & 6.790 & 6.790 \\
\hline
\end{tabular}

${ }^{1}$ Butylated hydroxytoluene.

${ }^{2}$ Quantity per kg of feed: vit. A - 7,200 IU; vit. $\mathrm{D}_{3}$ - 1,600 IU; vit. E - 5 IU; vit. $\mathrm{B}_{1}$ - $0.9 \mathrm{mg}$; vit. $\mathrm{B}_{2}$ - $2.7 \mathrm{mg}$; vit. $\mathrm{B}_{6}$ - $1.5 \mathrm{mg}$; calcium pantothenate - 5.9 mg; biotin - 0.02 mg; vit. $\mathrm{K}_{3}-1.1 \mathrm{mg}$; folic acid - $0.25 \mathrm{mg}$; niacin - $16 \mathrm{mg}$; vit. $\mathrm{B}_{12}-7.2 \mathrm{mcg}$; selenium - $0.25 \mathrm{mg}$

${ }^{3}$ Quantity per kg of feed: manganese - $75 \mathrm{mg}$; iron - $50 \mathrm{mg}$; zinc - $70 \mathrm{mg}$; copper - $8 \mathrm{mg}$; iodine - $0.75 \mathrm{mg}$. 
of the birds could be limited, compromising optimal determination of the ideal digestible tryptophan:digestible lysine ratio. The other nutrients and energy, except for crude protein, followed the recommendations by Rostagno et al. (2005).

The diets were provided daily at $8 \mathrm{~h} 00$ and $16 \mathrm{~h} 00$. During all the experiment, the maximum consumption of feed was limited to $95 \mathrm{~g} / \mathrm{bird} /$ day.

The lighting program adopted consisted of providing 17 hours light per day.

The experiment lasted 16 weeks. The following parameters were measured: feed intake, digestible tryptophan intake, digestible lysine intake, egg production, egg weight, egg mass, feed conversion per egg mass $(\mathrm{kg} / \mathrm{kg})$ and per dozen eggs $(\mathrm{kg} / \mathrm{dz})$, utilization efficiency of digestible lysine for eggs mass $(\mathrm{g} / \mathrm{g})$ and for number of eggs produced (no. eggs/g), percentage of egg components and weight gain.

The ideal digestible tryptophan:digestible lysine ratio was estimated using the variables studied, using analysis of variance, polynomial regression analysis and Linear Response Plateau (LRP) as better adjustment of data. The study adopted $\alpha=0.05$. The analyses were performed on the statistical analysis system program SAEG (Sistema para Análises Estatísticas e Genéticas, version 9.1).

\section{Results and Discussion}

During all experiment, the average maximum and minimum temperatures recorded inside the poultry house were 29.6 and $19.6{ }^{\circ} \mathrm{C}$ (Table 2). According to Tinoco (2001), the environment is considered comfortable to adult birds when the temperatures are $15-25{ }^{\circ} \mathrm{C}$. Thus, in some periods during the experiment, the birds were subjected to thermal stress.

The digestible tryptophan levels influenced $(\mathrm{P}<0.05)$ the feed intake of birds, which increased linearly in $4.08 \%$ (Table 3 ). This result was similar to that observed by Russell \& Harms (1999), Harms \& Russell (2000)

Table 2 - Mean temperatures (maximum and minimum) recorded inside the poultry house during the experimental period

\begin{tabular}{lcc}
\hline \multirow{2}{*}{ Weeks } & \multicolumn{2}{c}{ Temperatures $\left({ }^{\circ} \mathrm{C}\right)$} \\
\cline { 2 - 3 } $24-27$ & Maximum & Minimum \\
$28-31$ & $29.9(34.0)^{1}$ & $20.8(18.0)^{2}$ \\
$32-35$ & $32.0(35.0)^{1}$ & $20.5(18.0)^{2}$ \\
$36-39$ & $28.7(32.0)^{1}$ & $20.8(18.0)^{2}$ \\
Average & $27.6(30.0)^{1}$ & $16.4(13.0)^{2}$ \\
\hline
\end{tabular}

${ }^{1}$ Highest temperature recorded in the period.

${ }^{2}$ Lowest temperature recorded in the period.

Table 3 - Performance of laying hens from 24 to 40 weeks of age fed diets containing different digestible tryptophan:digestible lysine ratios

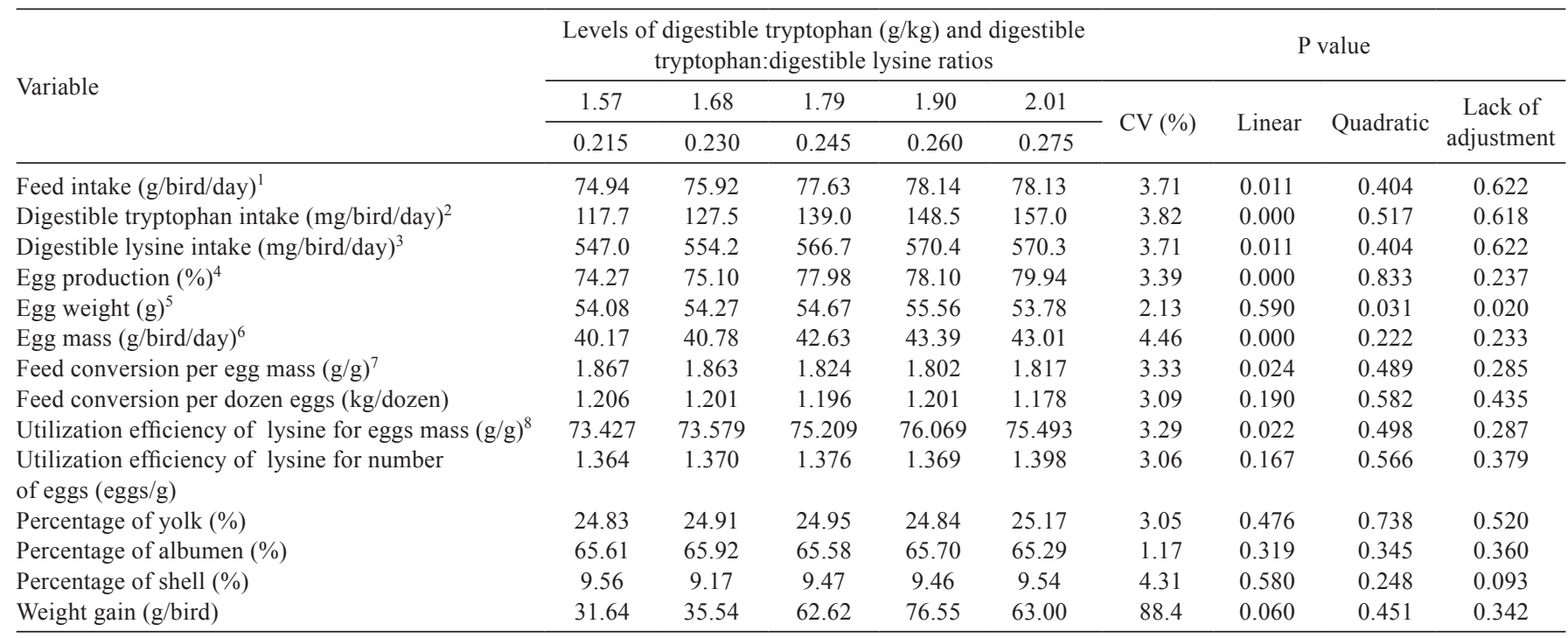

$\mathrm{CV}$ - coefficient of variation.

${ }^{1} \hat{\mathrm{y}}=62.9656+78.1270 \mathrm{x}\left(\mathrm{R}^{2}=0.88\right)$.

$2 \hat{\mathrm{y}}=-24.2722+906.159 x\left(\mathrm{R}^{2}=1.00\right)$.

${ }^{3} \hat{\mathrm{y}}=459.649+570.326 \mathrm{x}\left(\mathrm{R}^{2}=0.88\right)$.

${ }^{4} \hat{y}=53.7420+130.373 x\left(R^{2}=0.94\right)$.

${ }^{5} \hat{y}=-11.2032+732.871 x-2029.24 x^{2}\left(R^{2}=0.47\right)$.

${ }^{6} \hat{\mathrm{y}}=28.5072+75.3471 \mathrm{x}\left(\mathrm{R}^{2}=0.84\right)$

${ }^{7} \hat{y}=2.09798-1.47147 x\left(R^{2}=0.77\right)$.

${ }^{8} \hat{y}=63.9832+60.1799 x\left(R^{2}=0.78\right)$ 
and Peganova et al. (2003), who also found increase in the feed intake of laying hens due to the increased levels of tryptophan in the diet. According to Peganova \& Eder (2003), this positive effect on feed intake is because tryptophan is a precursor of serotonin, a neurotransmitter which has been attributed the function of regulating appetite in birds.

The birds had average daily feed intake (76.95 g) below the predetermined value of $95 \mathrm{~g}$. This low intake can be explained by the temperature, which was, in certain periods, above the range of thermoneutrality. Similarly, Carvalho (2005) evaluated the performance of laying hens receiving several levels of digestible tryptophan in the diets and also found low feed intake, explained by the high mean maximum temperature $\left(30^{\circ} \mathrm{C}\right)$ recorded during the experimental period. At elevated temperatures, birds have reduced ability to lose body heat to the environment and consequently tend to reduce feed intake. In addition, at 24 weeks, age at which the birds entered in the experiment, they were at the body weight $231 \mathrm{~g}$, which is below the standards for the strain, which may also have influenced feed intake.

Linear increase of $25.03 \%$ and $4.08 \%$ was observed in the consumption of digestible tryptophan $(\mathrm{P}<0.05)$ and digestible lysine $(\mathrm{P}<0.05)$ of the birds with increased levels of digestible tryptophan in the diet, respectively. There was increase in digestible tryptophan intake due to the increased levels of this amino acid in diets. In addition, the increase in the consumption of amino acids, including digestible lysine and digestible tryptophan, was also due to the increased feed intake by birds.

The egg production improved linearly $(\mathrm{P}<0.05)$ in $7.09 \%$ with increasing of levels of digestible tryptophan in the feed (Figure 1). This result was similar to the observed by Harms \& Russell (2000), who studied hens near the peak of production, which also showed an increase in egg production with the increase of tryptophan in the diet. In this study, one can affirm that the effect of dietary digestible tryptophan levels on feed intake was reflected on the production of eggs.

The production of eggs obtained at the level of $2.01 \mathrm{~g} / \mathrm{kg}$ of digestible tryptophan was lower than the recommended in the manual of the strain. This fact can be explained by the suboptimal level of digestible lysine in the diets used in this study. Similarly, Pinheiro et al. (2008), Brumano (2008) and Reis (2009), to estimate ideal ratios between essential amino acids and lysine for birds, also used suboptimal levels of digestible lysine in the diet. The suboptimal level is important to ensure that all digestible lysine consumed by birds be actually used and the digestible tryptophan: digestible lysine ratio be estimated accurately. A level of dietary digestible lysine beyond the usability of the birds can lead to underestimated digestible tryptophan:digestible lysine ratio. Furthermore, the feed intake was low, also affecting the egg production. However, as the objective of the study was to determine the ideal digestible tryptophan: digestible lysine ratio and not the absolute requirement of digestible tryptophan in $\mathrm{mg} / \mathrm{bird} / \mathrm{day}$, this lower egg production did not influence the reliability of estimates.

Egg weight improved $(\mathrm{P}<0.05)$ quadratically with the levels of digestible tryptophan in the diet, rising up to the level of $1.81 \mathrm{~g} / \mathrm{kg}$ (Figure 2). This level corresponded to an intake of $140 \mathrm{mg} / \mathrm{bird} /$ day of digestible tryptophan and the digestible tryptophan:digestible lysine ratio of 0.248 . The increase in egg weight in the present study is related not only to increased intake of digestible tryptophan, but also of other determinant nutrients such as methionine + cystine (Schmidt, 2006).

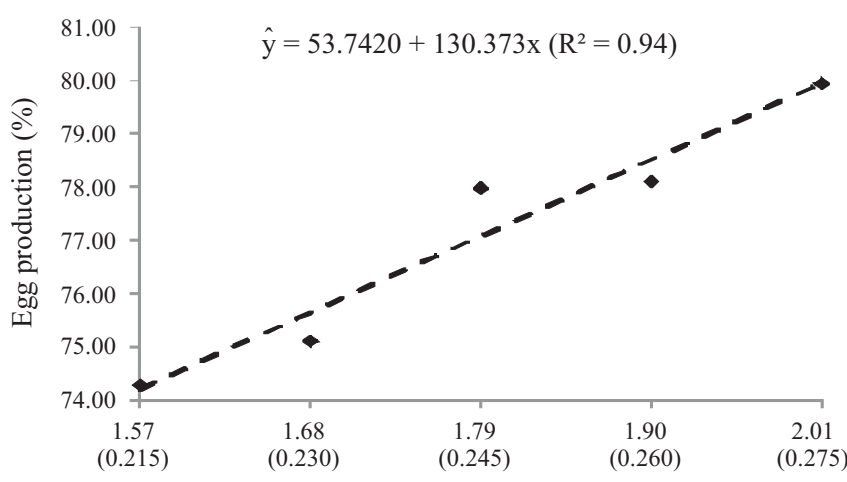

Digestible tryptophan $(\mathrm{g} / \mathrm{kg})$ and tryptophan: lysine ratios

Figure 1 - Effect of digestible tryptophan:digestible lysine ratios in the diet on egg production of laying hens from 24 to 40 weeks of age.

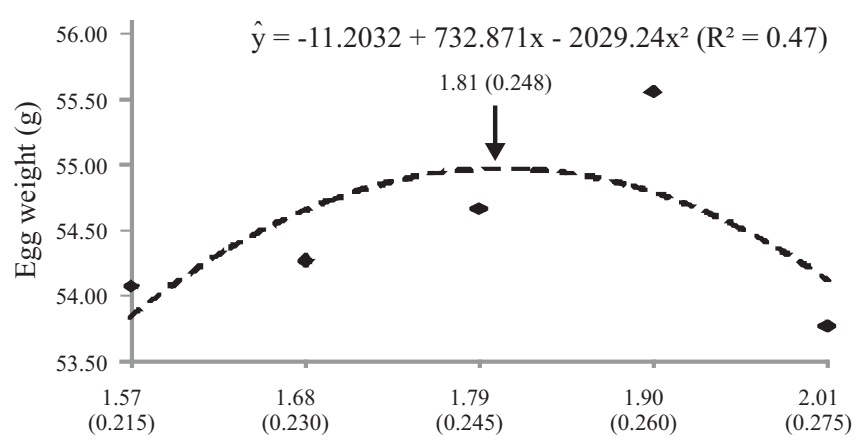

Digestible tryptophan $(\mathrm{g} / \mathrm{kg})$ and tryptophan:lysine ratios

Figure 2 - Effect of digestible tryptophan:digestible lysine ratios in the diet on egg weight of laying hens from 24 to 40 weeks of age.

R. Bras. Zootec., v.41, n.10, p.2176-2182, 2012 
The production of egg mass increased linearly $(\mathrm{P}<0.05)$ at $6.60 \%$ with increasing levels of digestible tryptophan in the diets (Figure 3). However, the LRP model showed a smaller sum of the squared deviations. The level of digestible tryptophan from which the plateau occurred was $1.86 \mathrm{~g} / \mathrm{kg}$, which was equivalent to the consumption of $144 \mathrm{mg} / \mathrm{bird} /$ day of digestible tryptophan and the digestible tryptophan:digestible lysine ratio of 0.255 . This result was similar to that observed by other authors, who also noted the influence of tryptophan levels in the diet on the production of egg mass (Russell \& Harms, 1999; Peganova et al., 2003; Carvalho, 2005). However, in the present study, this effect can also be associated with the increase in feed intake and other nutrients by the birds.

The feed conversion per eggs mass improved $(\mathrm{P}<0.05)$ linearly at $2.81 \%$ with increasing levels of digestible tryptophan in the diet (Figure 4). However, lower sum of squared deviations was obtained for the LRP model. The occurrence of the plateau was estimated from the level

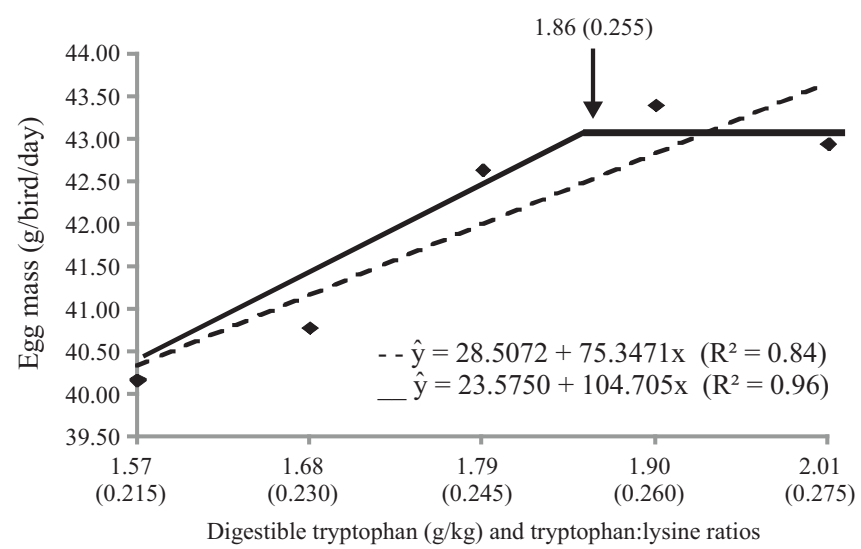

Figure 3 - Effect of digestible tryptophan:digestible lysine ratios in the diet on egg mass of laying hens from 24 to 40 weeks of age.

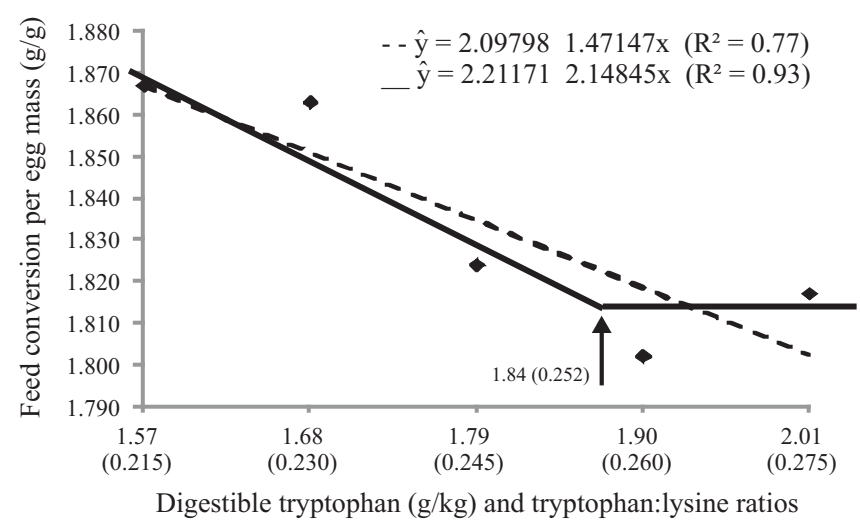

Figure 4 - Effect of digestible tryptophan:digestible lysine ratios in the diet on feed conversion per eggs mass of laying hens from 24 to 40 weeks of age. of $1.84 \%$ of digestible tryptophan in the diet. This level corresponded to the consumption of $142 \mathrm{mg} / \mathrm{bird} / \mathrm{day}$ of digestible tryptophan and the digestible tryptophan: digestible lysine ratio of 0.252 . The feed conversion per dozen eggs was not affected $(\mathrm{P}>0.05)$ by dietary digestible tryptophan levels in diets. The digestible tryptophan: digestible lysine ratio of 0.252 estimated in this study was higher than the value found by Lima et al. (2011) for feed conversion per eggs mass $(0.246 \%)$; however, it was similar to the value obtained by the same authors for feed conversion per dozen eggs $(0.253 \%)$ of hens from 29 to 45 weeks of age.

In experiments to establish ideal relations between essential amino acids and lysine, it is ideal that the feed intake of the birds for different treatments not present significant variation. A variation in feed intake results in variation in the amount of digestible lysine intake, which could influence the performance parameters of the birds. Thus, the effect of the amino acid levels in study may be masked by the increase in consumption of digestible lysine, leading to inconsistent relations estimated.

In this study, significant variation was observed in the feed intake of birds receiving different levels of digestible tryptophan in the diet. Thus, the digestible lysine intake varied in $23.3 \mathrm{mg} / \mathrm{bird} /$ day between the birds that received the highest $(2.01 \mathrm{~g} / \mathrm{kg})$ and lowest $(1.57 \mathrm{~g} / \mathrm{kg})$ levels of digestible tryptophan in the diet. Then, to determine the ideal digestible tryptophan:digestible lysine ratio, it was more important to evaluate the efficiency of utilization of digestible lysine by birds. The evaluation of this parameter enabled the isolation of the effect of digestible tryptophan in the diet on bird performance. Thus, the level of digestible tryptophan in the feed which maximizes the eggs mass production and/or the number of eggs per gram of digestible lysine intake is what establishes the best adjusted or ideal tryptophan:digestible lysine ratio.

The efficiency of utilization of digestible lysine for eggs mass improved $(\mathrm{P}<0.05)$ linearly at $2.81 \%$ with the increased level of digestible tryptophan in the diet (Figure 5). However, there was a better adjustment of the data to the LRP model with smaller sum of squared deviations. The level of digestible tryptophan in the feed from which the plateau occurred was $1.84 \mathrm{~g} / \mathrm{kg}$. This level corresponded to the consumption of $142 \mathrm{mg} / \mathrm{bird} /$ day of digestible tryptophan and a digestible tryptophan:digestible lysine ratio of 0.252 . The efficiency of utilization of digestible lysine for number of eggs produced was not affected $(\mathrm{P}>0.05)$ by the digestible tryptophan levels in the diet.

There was no effect $(\mathrm{P}>0.05)$ of the levels of digestible tryptophan in the diet on the percentage of yolk, albumen 


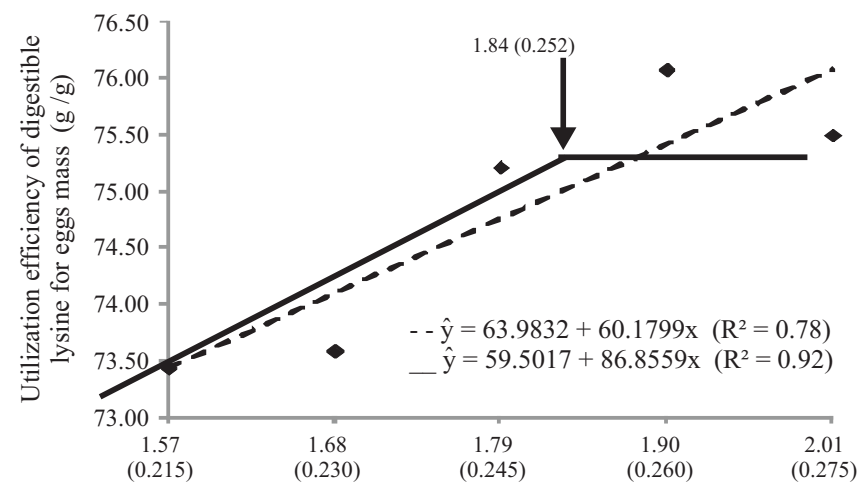

Digestible tryptophan $(\mathrm{g} / \mathrm{kg})$ and tryptophan:lysine ratios

Figure 5 - Effect of digestible tryptophan:digestible lysine ratios in the diet on the digestible lysine utilization efficiency for eggs from laying hens from 24 to 40 weeks of age.

and shell. This result contrasts with those obtained by Lima et al. (2010), who assessed different digestible tryptophan: digestible lysine ratios in the diet of laying hens from 29 to 45 weeks of age and observed a quadratic effect on the percentages of egg shell and yolk. The authors recommended a digestible tryptophan:digestible lysine ratio of 0.242 in the diet for better egg quality. The results from this study suggest that the digestible tryptophan:digestible lysine ratio of 0.215 was sufficient to maintain the quality of eggs.

There was no influence $(\mathrm{P}>0.05)$ from the levels of digestible tryptophan in the diet on the weight gain of birds. This result differed from that observed by Carvalho (2005), who found that hens fed diets with $1.16 \mathrm{~g} / \mathrm{kg}$ of digestible tryptophan had weight loss five times greater than those fed diets with $1.96 \mathrm{~g} / \mathrm{kg}$.

The ideal digestible tryptophan:digestible lysine ratio of 0.252 , estimated in this study based on the efficiency of utilization of digestible lysine for production of eggs mass was similar to the ratio of 0.253 estimated by Lima et al. (2011), based on the feed conversion per dozen eggs of hens from 29 to 45 weeks of age.

However, this ratio was higher than that obtained by Carvalho (2005), who, considering the parameters egg production, egg mass and feed conversion, estimated the ideal digestible tryptophan:digestible lysine ratio at 0.230 on average. However, the author adopted the digestible methionine + cystine:digestible lysine ratio of 0.874 and digestible threonine:digestible lysine of 0.627 , which are ratios that may be underestimated.

In recent research with laying hens, Brumano (2008) estimated the ideal digestible methionine + cystine:digestible lysine ratio at 1.00 and Rocha et al. (2009) estimated the ideal digestible threonine:digestible lysine ratio at 0.780 . One should consider that even if birds still have the potential to respond to increases in the digestible tryptophan: digestible lysine ratio in the diet, the performance gain may be limited if the ratios between other essential amino acids and digestible lysine are underestimated. This can lead to an underestimated digestible tryptophan:digestible lysine ratio. Also, Carvalho (2005) used the average of estimates obtained for egg production, egg mass and feed conversion, without considering the significant variation in feed intake, which may have compromised the tryptophan:digestible lysine ratio estimated.

The ratio between digestible tryptophan and digestible lysine estimated in this study was also higher than the 0.223 estimated by Bregendahl et al. (2008) for optimal production of egg mass of hens from 28 to 34 weeks of age. However, these authors used increasing levels of digestible lysine in the experimental diets, which can also make the estimation of the digestible tryptophan:digestible lysine ratio subjective.

\section{Conclusions}

The ideal digestible tryptophan:digestible lysine ratio recommended in diets for laying hens from 24 to 40 weeks of age is $0.252(25.2 \%)$.

\section{References}

BREGENDAHL, K.; ROBERTS, S.A.; KERR, B. et al. Ideal ratios of isoleucine, methionine, methionine plus cystine, threonine, tryptophan, and valine relative to lysine for white leghorn-type laying hens of twenty-eight to thirty-four weeks of age. Poultry Science, v.87, p.744-758, 2008.

BRUMANO, G. Níveis de metionina + cistina digestíveis em rações para poedeiras leves, nos períodos de 24 a 40 e de 42 a 58 semanas de idade. 2008. 89f. Tese (Doutorado em Zootecnia) - Universidade Federal de Viçosa, Viçosa, MG.

CARVALHO, D.C.O. Biodisponibilidade de fontes de metionina e exigências de nutricionais de lisina e de triptofano para poedeiras leves, mantidas em ambiente de alta temperatura, na fase de produção. 2005. 86f. Tese (Doutorado em Zootecnia) - Universidade Federal de Viçosa, Viçosa, MG.

DEPONTI, B.J.; FARIA, D.E.; FARIA FILHO, D.E. Exigências de triptofano e padrão de recuperação do desempenho de poedeiras comerciais após alimentação com rações deficientes em triptofano. Revista Brasileira de Zootecnia, v.36, p.1324-1330, 2007.

HARMS, R.H.; RUSSELL, G.B. Evaluation of tryptophan requirement of the commercial layer by using a corn-soybean meal basal diet. Poultry Science, v.79, p.740-742, 2000.

LIMA, M.R.; COSTA, F.G.P.; MORAIS, S.A.N. et al. Relação triptofano digestível: lisina digestível sobre a qualidade de ovos de poedeiras leves. In: REUNIÃO ANUAL DA SOCIEDADE BRASILEIRA DE ZOOTECNIA, 47., 2010, Salvador. Anais... Salvador: Sociedade Brasileira de Zootecnia, 2010. (CD-ROM).

LIMA, M.R.; COSTA, F.G.P.; MORAIS, S.A.N. et al. Digestible tryptophan: digestible lysine ratio on the performance of laying hens. In: INTERNATIONAL POULTRY SCIENTIFIC FORUM, 2011, Atlanta. Anais... Atlanta, GA, USA, 2011. 
PEGANOVA, S.; EDER, K. Interactions of various supplies of isoleucine, valine, leucine and tryptophan on the performance of laying hens. Poultry Science, v.82, p.100-105, 2003.

PEGANOVA, S.; HIRCHE, F.; EDER, K. Requirement of tryptophan in relation to the supply of large neutral amino acids in laying hens. Poultry Science, v.82, p.815-822, 2003.

PINHEIRO, S.R.F.; BARRETO, S.L.T.; ALBINO, L.F.T. et al. Efeito dos níveis de triptofano digestível em dietas para codornas japonesas em postura. Revista Brasileira de Zootecnia, v.37, p.1012-1016, 2008.

REIS, R.S. Relação metionina mais cistina com lisina em dietas para codornas japonesas em postura. 2009. 43f. Dissertação (Mestrado em Zootecnia) - Universidade Federal de Viçosa, Viçosa, MG.

ROCHA, T.C.; GOMES, P.C.; DONZELE, J.L. et al. Níveis de treonina digestível em rações para poedeiras leves no período de 24 a 40 semanas de idade. In: REUNIÃO ANUAL DA SOCIEDADE BRASILEIRA DE ZOOTECNIA, 46., 2009, Maringá. Anais... Maringá: Sociedade Brasileira de Zootecnia, 2009. (CD-ROM).

ROSTAGNO, H.S.; ALBINO, L.F.T.; DONZELE, J.L. et al. Tabelas brasileiras para aves e suínos: composição de alimentos e exigências nutricionais. Viçosa, MG: UFV, 2005. 186p.

RUSSEL, G.B.; HARMS, R.H. Tryptophan requirement of the commercial hen. Poultry Science, v.78, p.1283-1285, 1999.

SCHMIDT, M. Níveis nutricionais de lisina, de metionina+cistina e de treonina digestíveis para galinhas poedeiras no $2^{\circ}$ ciclo de produção. 2006. 101f. Tese (Doutorado em Zootecnia) Universidade Federal de Viçosa, Viçosa, MG.

TINÔCO, I.F.F. Avicultura industrial: novos conceitos de materiais, concepções e técnicas construtivas disponíveis para galpões avícolas brasileiros. Revista Brasileira de Ciência Avícola, v.3, p.1-26, 2001. 